\title{
PROFESIONALITAS PERANGKAT DESA PENGARUHNYA TERHADAP KUALITAS PELAYANAN PUBLIK DI KANTOR KEPALA DESA BADEAN BANGSALSARI
}

\author{
ADI SANTOSO* \\ REVALDI TRIO OKTA \\ Program Studi Ilmu Administrasi Negara \\ Sekolah Tinggi Ilmu Administrasi Pembangunan Jember \\ *Email: adi_santoso@stiapembangunanjember.ac.id
}

\begin{abstract}
ABSTRAK
Penelitian ini bertujuan unutk mengetahui sejauhmanakah pengaruh Profesional Perangkat Desa Terhadap Kualitas Pelayanan Publik yang bertempat di Kantor Kepala Desa Badean Kecamatan Bangsalsai Kabupeten Jember, Dugaan masalah dalam penelitian ini adalah Desa Badean Kecamatan Bangsalsari Kabupaten Jember belum memberikan tuntutan dalam memberikan pelayanan yang baik. Populasi dalam penelitian ini yaitu sebanyak 16 orang, sedangkan teknik pengambil sampel penelitian ini menggunakan Tekhnik sampel jenus, yaitu sebanyak 16 orang.. Analisis data dalam penelitian ini menggunakan korelasi statistik parametris, yaitu koefisien korelasi dan analisis regresi linear sederhana dengan jumlah populasi sebanyak 16 orang responden, sedangkan taraf signifikansi dalam penelitian ini yaitu sebesar 0,05 atau taraf kepercayaan 95\%. Dari hasil penelitian menunjukkan bahwa pengaruh Profesional Perangkat Desa mempunyai pengaruh yang kuat dan signifikan serta positif terhadap kualitas pelayanan Publik pada kantor Kepala Desa Badean Kecamatan Bangsalsari Kabupaten Jember.
\end{abstract}

Kata Kunci: Profesional Perangkat Desa, Kualitas Pelayanan Publik 


\section{PENDAHULUAN}

Kinerja pemerintah di bidang pelayanan publik menjadi isu kebijakan yang semakin strategis, karena perbaikan kinerja pemerintah memiliki pengaruh yang luas dalam kehidupan ekonomi dan politik. Dalam kehidupan ekonomi, perbaikan kinerja pemerintah akan bisa mempengaruhi iklim investasi yang amat diperlukan dalam mengakselerasi pembangunan di daerah. Sedangkan dari sisi politik, perbaikan kinerja pemerintah di bidang pelayanan publik akan memiliki dampak yang luas, terutama untuk memperbaiki tingkat kepercayaan masyarakat terhadap pemerintah.

Reformasi dan globalisasi yang terjadi di Indonesia telah banyak membawa perubahan bagi kehidupan bermasyarakat. Semenjak dikeluarkannya Undang-Undang Nomor 32 Tahun 2004 tentang Pemerintah Daerah, pemerintah daerah secara terus menerus dituntut untuk selalu berusaha meningkatkan pelayanan publik, sehingga tuntutan masyarakat untuk mendapatkan pelayanan yang berkualitas terus meningkat dari waktu ke waktu.

Banyak langkah yang harus direncanakan, dilakukan, dan dinilai secara sistematis dan konsisten. Penataan sumber daya aparatur yang profesional harus diprioritaskan, karena reformasi di bidang administrasi pemerintahan mengharapkan hadirnya pemerintah yang lebih berkualitas dan mampu mengemban fungsi-fungsi pelayanan publik.

Penanggung jawab fungsi pelayanan umum di Indonesia yang mengarahkan tujuannya kepada public service, yaitu harus memikirkan dan mengupayakan tercapainya sasaran pelayanan kepada seluruh masyarakat dalam berbagai lapisan. Tantangannya yang dihadapi dalam pelayanan publik adalah bukan hanya menciptakan sebuah pelayanan yang efisien dalam pelayanan tersebut, tetapi terdapat tiga unsur pokok yang harus diperhatikan yaitu biaya yang relatif lebih murah, waktu untuk mengerjakan relatif lebih cepat dan 
mutu yang diberikan relatif lebih bagus.

Beratnya tugas pemerintah yang mempersyaratkan tersedianya aktoraktor pemerintah, khususnya perangkat desa, tidak hanya dari segi jumlah tetapi juga memerlukan kemampuan profesionalisme dan kualitas moral yang berbanding lurus dengan tuntutan kebutuhan. Pengembangan sumber daya manusia dalam jajaran pemerintahan, khususnya pemerintah desa perlu diarahkan pada peningkatan kemampuan profesional dan pengembangan etika profesi yang disertai dengan semangat melayani kepada publik (masyarakat). Hal ini sejalan dengan perkembangan mutakhir dalam paradigma dan praktik administrasi bisnis saat ini, yang menempatkan konsumen sebagai pihak yang harus dilayani.

Masyarakat perlu dipuaskan melalui pemenuhan kebutuhannya, sehingga masyarakat merasa sebagai seorang raja. Mengingat masyarakat adalah raja, maka harus dilayani dengan baik. Berdasarkan pendapat di atas, dapat dijelaskan bahwa untuk dapat memberikan pelayanan yang baik kepada masyarakat, maka aparatur Pemerintah Desa perlu memiliki kemampuan profesional, karena hanya aparatur yang berkualitas dan memiliki kemampuan profesionalah yang mengetahui kebutuhan dan keinginan yang menjadi tuntutan masyarakat.

Perubahan - perubahan yang terjadi, telah membawa banyak kemajuan dalam berbagai aspek kehidupan masyarakat, tetapi di sisi lain perubahan tersebut telah meningkatkan tuntutan, harapan dan kebutuhan masyarakat akan kualitas pelayanan yang semakin baik. Untuk dapat memenuhi tuntutan dan kebutuhan masyarakat akan pelayanan yang semakin berkembang, Pemerintah Desa perlu sedini mungkin mengusahakan profesionalisme aparatur perangkat desa.

Misi pemerintah khususnya pemerintah desa adalah memberikan pelayanan yang sebaik-baiknya kepada masyarakat, dengan meningkatkan kualitas sumber daya manusia, sehingga bisa memberikan kesejahteraan dan rasa keadilan kepada masyarakat banyak. Akan 
tetapi masih ada dari perangkat desa yang mengabaikan pekerjaan melayani, yang sebenarnya menjadi tanggung jawabnya. Hal ini disebabkan karena masyarakat belum ditempatkan sebagai seorang raja.

Pemerintah desa sebagai unsur penyelenggara pemerintahan sangat berperan penting dalam kesejahteraan masyarakat, karena merekalah yang berhadapan langsung dengan masyarakat dalam memberikan pelayanan publik. Dalam pelaksanaan pelayanan publik di Kantor Kepala Desa Badean Bangsalsari yang direncanakan sebagai tempat penelitian masih terdapat kekurangan dalam memberikan pelayanan kepada masyarakat hal ini di sebabkan Karena kurangnya sarana computer dan masih rendahnya sumber daya manusia para aparatur pemerintah desa dalam penggunaaan TIK (Teknolgi Informasi dan Komunikasi), rendahnya tingkat kedisiplinan perangkat desa, adanya diskriminasi dan persyaratan yang berbelit-belit dan banyak ditemui para peranngkat desa yang bertugas hanya sekretaris desa dan sebagian dari beberapa kaur/kasi, dan juga seringkali kepala desa tidak ada ditempat sehingga dalam memberikan pelayanan kepada masyarakat seperti pembuatan surat keterangan kartu tanda penduduk (KTP), Kartu Keluarga (KK), surat keterangan akte kelahiran, Surat pengantar SKCK, Surat pindah Penduduk, Surat keterangan tidak mampu dan lain sebagainya berlangsung tidak efektif dan belum maksimal sehingga mempersulit masyarakat dalam mengurus kepentingan mereka.

Berdasarkan latar belakang yang telah diuraikan diatas, penulis tertarik untuk melakukan penelitian untuk mengetahui sejauhmana pengaruh profesional perangkat desa terhadap kualitas pelayanan publik di Kantor Kepala Desa Badean Bangsalsari. 


\section{TINJAUAN PUSTAKA}

\subsection{Manajemen Sumber Daya} Manusia

Manajemen Sumber Daya Manusia (MSDM) adalah proses memperoleh, melatih, dan memberikan kompensasi kepada karyawan, memperhatikan hubungan kerja mereka, kesehatan dan masalah keadilan. (Dessler, 2003:4). Manajemen sumber daya manusia didefinisikan sebagai suatu perencanaan pengorganisasian, pelaksanaan, dan pengawasan terhadap pengadaan, pengembangan, pemberian balas jasa, pengintegrasian, pemeliharaan, dan pemisahan tenaga kerja dalam rangka mencapai tujuan organisasi (Mangkunegara, 2001:2).

Manajemen sumber daya manusia adalah penarikan, seleksi, pengembangan, pemeliharaan, dan penggunaan sumber daya manusia untuk mencapai titik tujuan-tujuan individu maupun organisasi (Handoko, 2000:4). Manajemen sumber daya manusia merupakan suatu perencanaan, pengorganisasian, pengkoordinasian, pelaksanaan dan pengawasan terhadap pengadaan, pengembangan, pemberian balas jasa, pengintegrasian, pemeliharaan dan pemisahan tenaga kerja dalam rangka mencapai tujuan organisasi (Mangkunegara, 2002:2)

Dari pendapat di atas pengertian manajemen sumber daya manusia, maka dapat disimpulkan bahwa manajemen sumber daya manusia merupakan bagian dari manajemen keorganisasian yang menekankan pada unsur SDM dan sudah menjadi tugas manajemen sumber daya manusia untuk mengelola unsur manusia secara baik agar diperoleh tenaga kerja yang tepat sesuai pekerjaannya, sehingga mampu bekerja optimal demi tercapainya tujuan organisasi, yang dalam hal ini yaitu organisasi pemerintah di tingkat Desa.

\subsection{Teori Profesional}

Menurut Darmastuti (2006: 93) profesional dipahami sebagai suatu sifat yang dimiliki seseorang secara teknis dan operasional yang ditetapkan dalam batas batas etika profesi. Batas-batas etika profesi 
yang digunakan untuk mengatur profesional tidaknya seseorang dikaitkan dengan kode etik perilaku dan kode etik profesi sebagai standar moral yang berlaku dalam profesi tersebut. Secara ringkas dapat disimpulkan, untuk menjadi seorang profesional, ada beberapa sikap yang dituntut untuk dimiliki, yaitu; komitmen tinggi, tanggung jawab, berpikir obyektif, menguasai materi, berpikir sistematis.

Sedangkan menurut Muhammad (2001:58), profesional adalah profesi yang dirumuskan sebagai pekerjaan tetap bidang tertentu berdasarkan keahlian khusus yang dilakukan secara bertanggung jawab dengan tujuan memperoleh penghasilan. Kansil (2003:4) berpendapat bahwa profesional adalah sesuatu yang bersangkutan dengan profesi, sesuatu yang memerlukan kepandaian khusus untuk menjalankannya.

Dari pemahaman beberapa pendapat para ahli di atas dapat ditarik kesimpulan bahwa profesional adalah sebuah sikap dan sifat yang dimiliki oleh seseorang yang memiliki profesi dan memerlukan kepandaian khusus, keterampilan dan kemampuannya untuk menjalankannya dan, untuk melakukan pekerjaan, hidup dari pekerjaan itu, dan bangga akan pekerjaannya yang ditetapkan dalam batas batas etika profesi.

\subsection{Teori Profesionalisme}

Profesionalisme menurut Kusnadi (2002:16-17) adalah sikap dan pendirian serta karakteristik seseorang atau organisasi didalam melakukan suatu pekerjaan atau didalam menyelesaikan masalah yang dihadapi. Ada 6 unsur yang terkandung dalam profesionalisme yakni: 1) penguasaan atas bidang kerja atau masalah yang dihadapi; 2) serius dan tekun dalam menangani sesuatu yang dihadapi; 3) berpegang pada prinsip efektivitas dan efisien; 4) pantang menyerah (ulet); 5) terorganisir dan sistematis didalam menganalisis dan bertindak; dan 6) berfikir dan bertindak taktis dan strategis.

Menurut Sedarmayanti (2004:157), profesionalisme adalah suatu sikap atau keadaan dalam melaksanakan pekerjaan dengan memerlukan keahlian melalui 
pendidikan dan pelatihan tertentu dan dilakukan sebagai suatu pekerjaan yang menjadi sumber penghasilan dalam Sedarmayanti (2004:77) menyebutkan bahwa"profesionalisme adalah seorang pekerja yang terampil atau cakap dalam bekerja dan dituntut menguasai visi yang mendasari keterampilannya serta memiliki sikap yang positif dalam melaksanakan serta mengembangkan mutu karyanya".

Peraturan mengenai Diklat Pegawai Negeri Sipil, diatur dalam Pasal 31 Undang-undang No. 43 Tahun 1999, dimana bahwa untuk mencapai daya guna dan hasil guna yang sebesarbesarnya sehingga adanya pengaturan dan penyelenggaraan Pendidikan dan Pelatihan sesuai jabatan Pegawai Negeri Sipil. Sebagai pendukung dari definisi tersebut, dalam Pasal 1 Peraturan Pemerintah Nomor 101 Tahun 2000 mengenai Pendidikan dan Pelatihan jabatan, disebutkan bahwa Pendidikan dan Pelatihan yang selanjutnya disebut Diklat adalah proses penyelenggaraan belajar mengajar dalam rangka meningkatkan kemampuan Pegawai Negeri Sipil. Penyelenggaraan belajar mengajar dalam rangka meningkatkan kemampuan Pegawai Negeri Sipil.

Pendidikan dan pelatihan menurut Flippo yang dikutip oleh Hasibuan (2006:69), pendidikan adalah berhubungan dengan peningkatan pengetahuan dan pemahaman atas lingkungan kita secara menyeluruh, sedangkan pelatihan merupakan suatu usaha peningkatan pengetahuan dan keahlian seorang pegawai untuk mengerjakan suatu pekerjaan tertentu.

\section{Pendidikan}

Menurut UU SISDIKNAS No. 20 Tahun 2003, indikator pendidikan adalah berdasarkan tingkat/jenjang pendidikan (pendidikan formal) dan pendidikan nonformal. Pendidikan formal merupakan pendidikan yang diselenggarakan di sekolah melalui kegiatan belajar mengajar secara berjenjang dan berkesinambungan, sedangkan pendidikan nonformal merupakan pendidikan yang diselenggarakan di luar sekolah melalui kegiatan belajar mengajar 
yang tidak harus berjenjang dan berkesinambungan.

\section{Pelatihan}

Menurut Hardjanto (2012:69-70), pelatihan adalah bagian dari pendidikan. Pelatihan bersifat spesifik, praktis, dan segera. Spesifik berarti pelatihan berhubungan dengan bidang pekerjaan yang dilakukan. Praktis dan segera berarti yang sudah dilatihkan dapat dipraktikkan.

\subsection{Teori Pelayanan Publik}

Dalam Undang-Undang Nomor 25 Tahun 2009 Pasal 1 ayat (1) pengertian pelayanan publik adalah kegiatan atau rangkaian kegiatan dalam rangka pemenuhan kebutuhan pelayanan sesuai dengan peraturan perundang-undangan bagi setiap warga negara dan penduduk atas barang, jasa, dan/atau pelayanan administratif yang disediakan oleh penyelenggara pelayanan publik. Mahmudin (2007:213) menjelaskan pelayanan publik adalah segala kegiatan pelayanan yang dilaksanakan oleh penyelenggara pelayanan public sebagai upaya pemenuhan kebutuhan publik dan pelaksanaan ketentuan peratuaran perundang-undangan.

Penyelenggaraan pelayanan publik harus memiliki standar pelayanan dan dipublikasikan sebagai jaminan adanya kepastian bagi penerima pelayanan. Menurut Keputusan Menteri Pendayagunaan Aparatur Negara (PAN) Nomor 63 Tahun 2003 tentang Pedoman Umum Penyelenggaraan Pelayanan Publik, standar pelayanan merupakan ukuran yang dibakukan dalam penyelenggaraan pelayanan publik yang wajib diataati oleh pemberi dan atau penerima pelayanan yang meliputi prosedur pelayanan, waktu penyelesaian, biaya pelayanan, produk pelayanan, saranan dan prasarana, kompetensi petugas pemberi pelayanan.

Dalam proses kegiatan pelayanan diatur juga mengenai prinsip pelayanan sebagai pegangan dalam mendukung jalannya kegiatan. Adapun prinsip pelayanan publik menurut keputusan Menteri PAN Nomor 63 Tahun 2003 antara lain kesederhanaan, kejelasan, kepastian waktu, akurasi, keamanan, tanggung jawab, kelengkapan sarana dan 
prasarana, kemudahan akses, berkualitas apabila dapat kedisiplinan, kesopanan dan menyediakan produk dan jasa keramahan serta kenyamanan.

(pelayanan) sesuai dengan kebutuhan dan harapan pelanggan. Dalam hal

2.5 Teori Kualitas Pelayanan Publik

Sampara (1999) dalam

Hardiyansyah

(2011:35)

mengemukakan bahwa kualitas pelayanan adalah pelayanan yang diberikan kepada pelanggan sesuai dengan standar pelayanan yang telah dibakukan dalam memberikan layanan sebagai pembakuan pelayanan yang baik. Sementara itu menurut Ibrahim (2008:22) dalam Hardiyansyah (2011:40), kualitas pelayanan publik merupakan suatu kondisi dinamis yang berhubungan dengan produk, jasa, manusia, proses, dan lingkungan dimana penilaian kualitasnya ditentukan pada saat terjadi pemberian pelayanan publik tersebut.

Menurut Goetsch dan Davis dalam Hardiyansyah (2011:36), menyatakan bahwa: Kualitas pelayanan adalah sesuatu yang berhubungan dengan terpenuhinya harapan/kebutuhan pelanggan, dimana pelayanan dikatakan ini, kualitas pada dasarnya terkait dengan pelayanan yang baik, yaitu sikap atau cara karyawan dalam melayani pelanggan atau masyarakat secara memuaskan.

Berdasarkan pendapat para ahli di atas yang mengenai pengertian kualitas pelayanan publik, dapat disimpulkan bahwa kualitas pelayanan publik adalah totalitas dari kemampuan pihak penyelenggara pelayanan yang dalam hal ini yaitu Perangkat Desa dalam memberikan pelayanan administrasi pemerintahan kepada masyarakat, yang dapat memenuhi kebutuhan dan dapat memberikan kepuasan kepada masyarakat berdasarkan kesesuaian dengan harapan dan kenyataan yang diterima oleh masyarakat.

Menurut

Zeithhaml, Parasuraman \& Berry (dalam Hardiansyah 2011:46) untuk mengetahui kualitas pelayanan yang dirasakan secara nyata oleh konsumen, ada indikator kualitas 
pelayanan yang terletak pada lima dimensi kualitas pelayanan, yaitu:

1. Tangibles (berwujud): kualitas pelayanan berupa sarana fisik perkantoran, komputerisasi administrasi, ruang tunggu, tempat informasi.

2. Realibility (kehandalan): kemampuan dan keandalan untuk menyediakan pelayanan yang terpercaya

3. Responsivess (ketanggapan): kesanggupan untuk membantu dan menyediakan pelayanan secara cepat dan tepat, serta tanggap terhadap keinginan konsumen

4. Assurance (jaminan): kemampuan dan keramahan serta sopan santun pegawai dalam meyakinkan kepercayaan konsumen

5. Emphaty (Empati): sikap tegas tetapi penuh perhatian dari pegawai terhadap konsumen.

2.6 Teori Penghubung Profesionalisme Dengan Kualitas Pelayanan

Menurut pendapat Siagian (2000:163), profesionalisme merupakan keandalan dalam pelaksanaan tugas sehingga terlaksana dengan mutu tinggi, waktu yang tepat, cermat dan dengan prosedur yang mudah dipahami dan diikuti oleh pelanggan.

Berdasarkan pendapat di atas Perangkat Desa yang profesional akan handal dalam bertugas yang pada akhirnya akan menghasilkan kerja yang bermutu tinggi, waktu yang tepat dan prosedur yang bisa diikuti masyarakat yang dilayaninya. Supaya handal tentunya dibutuhkan pendidikan dan pelatihan tertentu yang akan mendukung Perangkat Desa dalam bekerja agar dapat merespon kebutuhan dan perkembangan lingkungan yang semakin pesat pada era otonomi sekarang agar bisa melayani kepentingan masyarakat secara efektif dan memiliki daya inovatif yang tinggi dan bisa mengacu pada visi dan misi organisasi.

\subsection{Kerangka Pemikiran}

Berdasarkan kerangka pemikiran indikator yang peneliti gunakan adalah pendidikan dan pelatihan untuk variabel (X), 
sedangkan untuk variabel (Y) peneliti menggunakan 5 indikator yaitu terdiri dari tangible (berwujud), reliability

(kehandalan), responsiveness

(tanggapan), (jaminan/kepastian), empathy (perhatian).

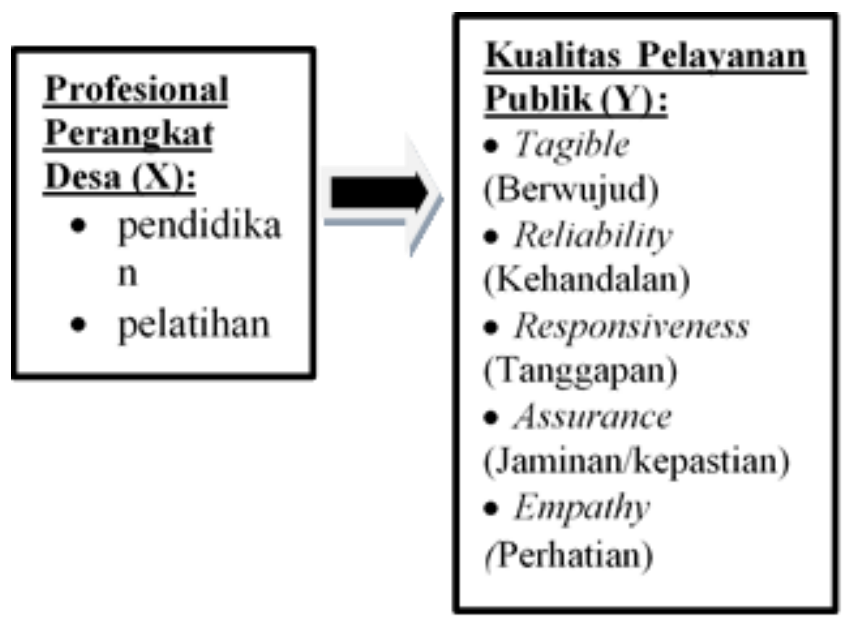

Gambar 1. Kerangka Pemikiran

\subsection{Hipotesis}

Sutrisno

Hadi

(2000:63)

mengatakan bahwa "hipotesa adalah dugaan yang mungkin benar atau mungkin salah, dia akan ditolak jika salah satu palsu dan akan diterima jika fakta-faktanya membenarkan hipotesa itu dapat juga dipandang sebagai konklusi yang sifatnya sementara".

$\mathrm{H}_{\mathrm{a}}$ : Terdapat pengaruh antara profesional perangkat desa terhadap kualitas pelayanan publik di Kantor Kepala Desa Badean Bangsalsari.

$\mathrm{H}_{0}$ : Tidak terdapat pengaruh antara profesional perangkat desa terhadap kualitas pelayanan publik di Kantor Kepala Desa Badean Bangsalsari. 


\section{METODE PENELITIAN}

Lokasi penelitian yang penulis laksanakan adalah di Kantor Kepala Desa Badean Bangsalsari Jember dengan alasan ingin mengetahui sejauhmana pengaruh professional perangkat desa terhadap kualitas pelayanan publik di Kantor Kepala Desa Badean Bangsalsari. Dalam penelitian ini peneliti menggunakan jenis data ordinal. Data yang digunakan dalam penelitian ini adalah data primer dan sekunder. Jenis penelitian yang digunakan dalam penelitian ini termasuk penelitian asosiatif dengan analisa kuantitatif. Data kuantitatif adalah data yang berbentuk angka atau data kualitatif yang diangkakan. Data kualitatif yang diangkakan (skoring) misalnya terdapat dalam skala pengukuran. Sedangkan populasi dalam penelitian ini yaitu seluruh perangkat Desa Badean Bangsalsari yang berjumlah 16 orang. Adapun penarikan sampel yang dilakukan dalam penelitian ini yaitu jenis sampel jenuh atau sensus, yaitu sebanyak 16 perangkat Desa Badean Bangsalsari.

Pengambilan data dalam penelitian ini menggunakan teknik observasi, kuesioner, wawancara, dan dokumentasi. Analisis data dalam penelitian ini menggunakan regresi linear sederhana dengan jumlah populasi sebanyak 16 orang responden.

\section{HASIL PENELITIAN DAN PEMBAHASAN}

Hasil yang diperoleh dari pengolahan data primer kuesioner, menunjukkan bahwa usia responden yang terbanyak berada pada usia 5160 tahun yaitu sebanyak 8 orang (50\%). Seluruh pegawai Kantor Kepala Desa Badean berjenis kelamin laki-laki (100\%). Status perkawinan menunjukkan bahwa seluruh responden berstatus kawin (100\%). Sebagian besar responden berpendidikan terakhir SMA atau sederajat sebanyak 9 orang $(56,25 \%)$.

Penelitian ini terdiri dari 2 variabel, yaitu variabel profesional perangkat desa sebagai variabel independen dan variabel kualitas 
pelayanan publik sebagai variabel dependen. Variabel profesional perangkat desa diukur melalui indikator pendidikan dan pelatihan, sedangkan untuk variabel kualitas pelayanan diukur melalui 5 indikator yaitu tangible (berwujud), reliability (kehandalan), responsiveness (ketanggapan), assurance (jaminan), dan emphaty (empati).
Sampel dalam penelitian ini adalah $\mathrm{N}=16$, dan taraf siginifikan 95\% atau alpha $(\alpha)$ 5\% diperoleh $r_{\text {tabel }}=0,497$. Jika $r_{\text {hitung }}>r_{\text {tabel }}$ dan nilai positif maka butir pernyataan valid. Perbandingan antara nilai $r_{\text {hitung }}$ dan $r_{\text {tabel }}$ disajikan dalam tabel berikut:

Tabel 1. Hasil Uji Validitas

\begin{tabular}{|c|c|c|c|}
\hline Item Peryataan & $\mathrm{r}_{\text {hitumg }}$ & $\mathrm{r}_{\text {tabel }}$ & Keterangan \\
\hline \multicolumn{4}{|c|}{ Profesional Perangkat Desa (X) } \\
\hline Item $1 \mathrm{X}_{1.1 .1}$ & 0,750 & 0,497 & Valid \\
\hline Item $2 X_{1.1 .2}$ & 0,529 & 0,497 & Valid \\
\hline Item $3 \mathrm{X}_{1.2 .1}$ & 0,635 & 0,497 & Valid \\
\hline Item $4 X_{1.2 .2}$ & 0,800 & 0,497 & Valid \\
\hline Item $5 X_{1.2 .3}$ & 0,820 & 0,497 & Valid \\
\hline Item $6 \mathrm{X}_{1.2 .4}$ & 0,728 & 0,497 & Valid \\
\hline Item $7 \mathrm{X}_{1.2 .5}$ & 0,697 & 0,497 & Valid \\
\hline \multicolumn{4}{|c|}{ Kualitas Pelayanan Publik (Y) } \\
\hline Item $1 \mathrm{Y}_{1.1 .1}$ & 0,789 & 0,497 & Valid \\
\hline Item $2 Y_{1.1 .2}$ & 0,717 & 0,497 & Valid \\
\hline Item $3 \mathrm{Y}_{1.2 .1}$ & 0,722 & 0,497 & Valid \\
\hline Item $4 Y_{1.2 .2}$ & 0,580 & 0,497 & Valid \\
\hline Item $5 \mathrm{Y}_{1.3 .1}$ & 0,539 & 0,497 & Valid \\
\hline Item $6 \mathrm{Y}_{1.3 .2}$ & 0,850 & 0,497 & Valid \\
\hline Item $7 \mathrm{Y}_{1.4 .1}$ & 0,552 & 0,497 & Valid \\
\hline Item $8 \mathrm{Y}_{1.4 .2}$ & 0,636 & 0,497 & Valid \\
\hline Item $9 Y_{1.5 .1}$ & 0,630 & 0,497 & Valid \\
\hline Item $10 \mathrm{Y}_{1.5 .2}$ & 0,678 & 0,497 & Valid \\
\hline
\end{tabular}

Berdasarkan Tabel 1, dapat dilihat bahwa seluruh butir pernyataan yang berjumlah 7 pernyataan untuk variabel profesional perangkat desa $(\mathrm{X})$ dan
10 pernyataan untuk variabel kualitas pelayanan publik (Y) memiliki nilai $\mathrm{r}_{\text {hitung }}>\mathrm{r}_{\text {tabel. }}$ Maka dapat disimpulkan bahwa seluruh butir pernyataan yang digunakan dalam 
penelitian ini dapat dikatakan valid dan layak digunakan sebagai alat ukur dalam penelitian ini.

Berdasarkan hasil uji reliabilitas menunjukkan bahwa nilai Cronbach's Alpha sebesar 0,828 untuk variabel profesional perangkat desa $(\mathrm{X})$ dan 0,879 untuk variabel kualitas pelayanan publik (Y). Nilai tersebut lebih besar dari 0,06, artinya seluruh butir pernyataan yang digunakan dalam penelitian ini bersifat konsisten dan reliabel.

Tabel 2. Hasil Uji Reliabilitas

\begin{tabular}{|l|c|c|}
\hline \multicolumn{1}{|c|}{ Variabel } & Cronbach's Alpha & Keterangan \\
\hline $\begin{array}{l}\text { Profesional perangkat desa } \\
\text { (X) }\end{array}$ & 0,828 & Reliabel \\
\hline $\begin{array}{l}\text { kualitas pelayanan publik } \\
(Y)\end{array}$ & 0,879 & Reliabel \\
\hline
\end{tabular}

Koefisien determinasi $\left(\mathrm{R}^{2}\right)$ terhadap variabel kualitas pelayanan digunakan untuk mengetahui persentase kontribusi variabel publik (Y), yang dapat dilihat pada profesional perangkat desa (X) Tabel 3.

Tabel 3. Hasil Uji Koefisien Determinasi $\left(\mathrm{R}^{2}\right)$

\begin{tabular}{|c|c|c|c|c|}
\hline \multicolumn{5}{|c|}{ Model Summary } \\
\hline \multirow{2}{*}{ Model } & $\mathrm{R}$ & R Square & $\begin{array}{c}\text { Adjusted R } \\
\text { Square }\end{array}$ & $\begin{array}{c}\text { Std. Error of } \\
\text { the Estimate }\end{array}$ \\
\hline 1 & $.831^{\mathrm{a}}$ & .691 & .669 & 2.68821 \\
\hline
\end{tabular}

a. Predictors: (Constant), Profesional Perangkat Desa

Tabel 3 di atas menjelaskan besarnya nilai korelasi/hubungan (R) yaitu sebesar 0,831. Dari hasil tesebut dapat dikatakan bahwa terdapat hubungan antara variabel profesionalisme pegawai terhadap variabel kualitas pelayanan publik sebesar 0,831. Besarnya koefisien determinasi $\left(\mathrm{R}^{2}\right)$ sebesar 0,691 yang berarti bahwa pengaruh variabel profesional perangkat desa terhadap variabel kualitas pelayanan publik 
adalah sebesar $69,1 \%$. sedangkan oleh variabel lain.

sisanya sebesar $30,9 \%$ dipengaruhi

Tabel 4. Hasil Uji t

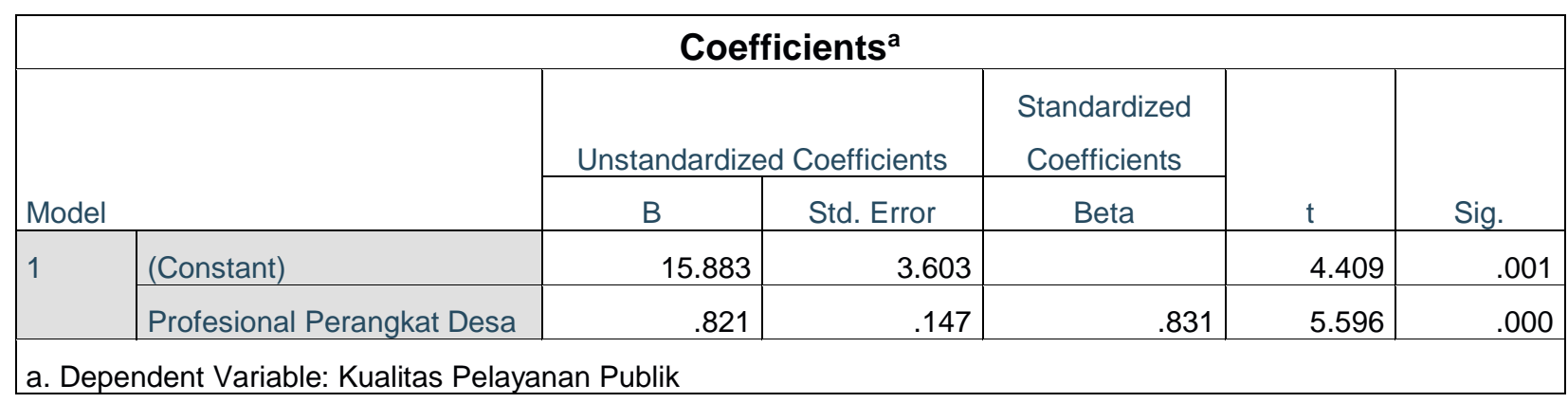

Berdasarkan Tabel 4 dapat diperoleh persamaan regresi linier sederhana sebagai berikut:

$$
\begin{aligned}
Y & =a+b X \\
& =15,883+0,821 X
\end{aligned}
$$

Berdasarkan hasil analisis di atas dapat dinyatakan sebagai berikut:

1. Konstanta sebesar 15,883 . Artinya bahwa nilai konsisten variabel kualitas pelayanan adalah sebesar 15,883 .

2. Koefisien regresi $b=0,821$ menyatakan bahwa setiap penambahan $1 \%$ nilai variabel profesional perangkat desa, maka nilai variabel kualitas pelayanan publik bertambah sebesar $0,821 \%$. Koefisien regresi tersebut bernilai positif, sehingga dapat dikatakan bahwa arah pengaruh antara variabel $\mathrm{X}$ (profesiona perangkat desa) terhadap variabel $\mathrm{Y}$ (kualitas pelayanan publik) berjalan searah.

Langkah terakhir dari analisis regresi linier sederhana adalah pengkajian taraf kepercayaan (signifikansi). Adapun taraf signifikansi yang peneliti gunakan adalah sebesar 0,05 atau taraf kepercayaan $95 \%$. Apabila ternyata nilai sign $<\alpha$, maka $\mathrm{H}_{\mathrm{a}}$ diterima dan $\mathrm{H}_{0}$ ditolak. Sebaliknya jika nilai sign $>\alpha$ maka $\mathrm{H}_{0}$ diterima dan $\mathrm{H}_{\mathrm{a}}$ ditolak.

Tabel 4 menunjukan bahwa nilai sign $<\alpha$ dengan nilai $0,000<0,005$, ini menunjukkan bahwa $\mathrm{H}_{\mathrm{a}}$ diterima dan $\mathrm{H}_{0}$ ditolak. Artinya, variabel profesional perangkat desa (X) 
mempunyai pengaruh positif dan signifikan terhadap variabel kualitas pelayanan publik (Y), sehingga hipotesis yang menyatakan bahwa terdapat pengaruh profesional perangkat desa tehadap kualitas pelayanan publik di Kantor Kepala Desa Badean Bangsalsari terbukti kebenarannya atau $\mathrm{H}_{\mathrm{a}}$ diterima.

Penelitian ini menemukan bahwa profesional perangkat desa berpengaruh signifikan terhadap kualitas pelayanan. Hal ini dapat diartikan bahwa variabel-variabel

\section{KESIMPULAN DAN SARAN}

\subsection{Kesimpulan}

Kesimpulan dalam penelitian merupakan jawaban dari tujuan penelitian ini. Hasil dari analisis regresi linier sederhana yang digunakan oleh penulis dengan bantuan program software SPSS Versi 25 yang menguji tentang pengaruh profesional perangkat desa terhadap kualitas pelayanan publik di Kantor Kepala Desa Badean Bangsalsari, menunjukkan bahwa profesional perangkat desa mempunyai pengaruh positif serta signifikan terhadap kualitas profesional perangkat desa mampu untuk menigkatkan kualitas pelayanan publik yang ada di Kantor Kepala Desa Badean Bangsalsari. Hasil penelitian ini mendukung hasil penelitian yang dilakukan oleh Andila Mandasari (2014) dimana profesionalisme pegawai mempunyai pengaruh yang kuat dan bernilai positif serta signifikan terhadap kualitas pelayanan di Kantor Dinas Kependudukan dan Pencatatan Sipil Kabupaten Kutai Barat.

pelayanan publik di Kantor Kepala Desa Badean Bangsalsari. Sehingga hipotesis yang menyatakan bahwa ada pengaruh profesional perangkat desa terhadap kualitas pelayanan publik di Kantor Kepala Desa Badean Bangsalsari terbukti kebenarannya atau $\mathrm{H}_{\mathrm{a}}$ diterima.

\subsection{Saran}

Berdasarkan dengan hasil penelitian dan kesimpulan yang telah dikemukakan maka penulis memberikan saran yaitu hendaknya instansi pemerintah Desa Badean 
Bangsalsari selalu memperhatikan faktor-faktor profesional perangkat desa seperti displin kerja, keahlian atau kehandalan perangkat desa dalam bekerja dan mempergunakan

\section{DAFTAR PUSTAKA}

Darmastuti, Rini. 2006. Etika PR dan $E-P R$. Yogyakarta: Gava Media.

Dessler, Gary. 2003. Sumber Daya Manusia. Klaten: PT. Intan Sejati.

Hardiansyah. 2011. Kualitas Pelayanan Publik. Yogyakarta: Gava Media.

Hadi, Sutrisno. 2000. Metodologi Penelitian. Yogyakarta: Andi.

Siagian, Sondang P. 2000. Teori Pengembangan Organisasi. Jakarta: Bumi Aksara.

Sedarmayanti. 2004. Good Governance (Kepemerintahan yang Baik) dalam Rangka Otonomi Daerah Upaya Membangun Organisasi Efektif dan Efisien melalui Restrukturisasi dan Pemberdayaan. Bandung: Mandar Maju.

Undang-Undang Nomor 32 Tahun 2004 tentang Pemerintah Daerah.

Undang-Undang Nomor 25 Tahun 2009 tentang Pelayanan Publik. alat bantu dalam memberikan

pelayanan publik. Hal ini dikarenakan profesional perangkat desa akan meningkatkan kualitas pelayanan publik. 